\title{
Research on Internal Accounting Control in Colleges and Universities
}

\author{
Xiangling Yu \\ Shandong Jiaotong University, Weihai, Shandong, China
}

Keywords: Internal accounting control; The framework of control; Construction; Process optimization

\begin{abstract}
With the rapid development of discipline construction and improvement of teaching service facilities in colleges and universities, the economic scope involved in colleges and universities is also constantly expanding. In addition to state funding and tuition fees, most universities in the country can raise and use funds independently. However, at the same time of rapid development, colleges and universities have not yet established a perfect internal accounting control system. At the same time, the management of colleges and universities has not paid enough attention to the internal accounting control system, resulting in frequent problems in the construction of teaching infrastructure, management of fixed assets in colleges and universities, recruitment and employment mode of colleges and universities and the use of scientific research funds. Therefore, on the basis of a comprehensive review of the connotation, development and current situation of the internal accounting control theory, this paper aims to construct a scientific, reasonable and practical internal accounting control system in colleges and universities in view of the current situation of the internal accounting control in colleges and universities.
\end{abstract}

\section{Introduction}

In response to the country's deepening reform and opening up and promoting the integration of colleges and universities in the language, as the national and social talent Training, scientific research Highland colleges and universities are constantly seeking reform and innovation, from the university's reform results, the role and functions of colleges and universities have gradually changed, Colleges and universities from the traditional public welfare organization gradually changed to have an independent legal personality of the institutions, and the most worthy of our attention is the financial source of higher education has undergone a significant change, from the national financial education to expand the special allocation to diversify the financing channels, colleges and universities actively participate in economic activities at the same time, The complexity of internal and external environment in colleges and universities has been increased, which has won full autonomy for colleges and universities, and put forward greater challenges for internal accounting control.

From the point of view of capital absorption and utilization, the paper presents a wide range of financing channels for the construction work of colleges and universities, and the second is that higher education institutions including their subordinate level two colleges have abundant resources endowment, and the tertiary institutions are not fully connected with market economy, and there are many places to be improved in management idea and management mode. The weak links in the internal accounting control and the relatively weak and backward management consciousness of colleges and universities bring the loopholes in the management, which makes the economic problems of colleges and universities bring about economic losses, and brings the heavy load to the scientific research management of colleges and universities.

2013-2014, due to the lack of construction of internal accounting control system and the implementation of internal accounting control system, some colleges and universities in the construction of basic facilities such as teaching, college admission and Employment, and the management of state-owned assets to leave school. A glimpse of the whole picture, because of the 
weak consciousness of internal accounting control, imperfect internal accounting control system, and the lack of internal supervision mechanism, the internal accounting control of colleges and universities cannot become the supervision and management tool of the economic crime in higher institutions, so it is urgent to strengthen the internal accounting control.

\section{Theoretical Summary of Internal Accounting Control in Colleges and Universities}

In the process of enterprise development, internal accounting control is more and more mentioned. Internal accounting control adheres to the characteristics of control functions, emphasizing the targeted and planned monitoring of enterprise development. There is a substantial internal relationship between internal accounting control and internal control. Internal control internal control is the theoretical basis, focusing on top-down internal control processes and improving the operational efficiency of enterprises through accounting systems.

Combined with the definition of internal accounting control, the basic functions of accounting and the definition of internal accounting control by other scholars, this paper defines the internal accounting control of colleges and universities as the management system implemented by higher education institutions to ensure the quality of accounting, property security and promote the healthy development of colleges and universities. This management system consists of mutually interconnected and mutually constrained methods and institutional measures.

The development of internal accounting control in enterprises is earlier than the internal accounting control of universities. At present, the company has established a relatively mature internal accounting control system. The mature system of internal accounting control provides reference and reference for the internal accounting control of colleges and universities. However, as a non-profit organization, colleges and universities have a large difference between their internal accounting control and internal accounting control.

The development of internal accounting control in our country is mainly concentrated after the reform and opening up. In 1985, the introduction of the first "Accounting Law" marked the introduction of China's internal accounting control, and the subsequent development of internal accounting control was accompanied by the revision and improvement of relevant laws. After entering the year 2000, the development of the internal accounting control system has formed a framework system for internal accounting control of enterprises in China from the basic operational norms of enterprise internal accounting control, risk management and risk assessment, and the business management environment.

\subsection{The Elements of Internal Accounting Control in Colleges and Universities}

Through reviewing the previous literature, it is found that internal accounting control is closely related to internal control. The research basis of internal accounting control is internal control theory. The internal accounting control of colleges and universities is based on the theory of internal accounting control. In view of the significant differences between universities and enterprises, the internal accounting control of colleges and universities is mainly composed of the following aspects:

\subsection{Internal accounting control environment}

The internal accounting control of colleges and universities is based on the environment of higher education institutions. Higher education institutions assume more social responsibilities and assume the responsibility of public higher education. This is a company that is obviously different from $\mathrm{W}$ for profit. Therefore, the internal accounting control of colleges and universities should be based on the university environment, and the internal accounting control environment of the university is also the basis of the internal accounting control of other elements. According to the characteristics of colleges and universities, the content of the internal accounting control environment of colleges and universities can be further divided into the competence of human resources, the culture of colleges and universities, the basic financial policies of colleges and universities, and the financial management methods. 
Objectives and risk assessment of internal accounting controls

- Internal accounting control activities

- Internal accounting control supervision

- Internal accounting control information sharing

\section{Analysis of the Status Quo and Problems of Internal Accounting Control in Chinese Universities}

In recent years, China's education expenditures have shown a clear growth trend, and China's higher education has also ushered in a good opportunity for vigorous development. Under the background of the national revitalization education, universities have closely followed the development opportunities, and universities have formed educational development alliances, such as "NATO", "Huayo" and "excellent alliance", and some universities actively participate in national higher education. Development plans, such as "111 plan". Major universities across the country have seized the stage of strategic development opportunities, expanded the enrollment scale, developed the campus area, improved the campus infrastructure construction, and built a branch campus, showing a good development trend. Although colleges and enterprises have the same needs in internal accounting control, colleges and universities are different from enterprises, and their internal accounting control system is rather backward, which restricts the development of colleges and universities to a certain extent. Therefore, analyzing the status quo and problems existing in the internal accounting control of colleges and universities, and repairing and perfecting the problems are of great significance for the construction of internal accounting control system in colleges and universities.

Because there are many studies on internal accounting control and internal accounting control in colleges and universities, through the analysis of the literature, the internal accounting control for different entities such as enterprises and universities, the measurement of internal accounting control mainly uses the internal accounting proposed by COSO. The control framework mainly includes five dimensions: internal accounting control environment, internal accounting control risk assessment, internal accounting control activities and processes, internal accounting control information sharing, and internal accounting control supervision. Prof. Gao Yibin from the Institute of Fiscal Science of the Ministry of Finance and his team put forward the initial framework of internal accounting control in the research. After extensive citation, it was recognized by other researchers. An index system for internal accounting control was constructed, which consisted of 33 items with 9 dimensions. Professor Zhu Rongen and his team also proposed 29 items in 5 dimensions in the study of internal accounting control, and investigated the effects of internal accounting control.

\section{Analysis on the Problems Existing in the Internal Accounting Control of Colleges and Universities}

\subsection{Internal accounting control environment analysis}

What is different from the development of higher education in Western countries is that Chinese universities lack the support of modern management theory in the development process. The management of colleges and universities in China is carried out by the leadership of the party committee, the principal is responsible, and the development path of the university leaders is also limited. That is, the leaders of colleges and universities need to make a decision in this field before they turn to administrative positions. The leaders are all professors, all of whom are highly regarded scholars and experts in their respective fields. Very few colleges and universities are equipped with full-time executive vice presidents.

The lack of professional internal accounting control management theory and knowledge in the leadership of colleges and universities is limited, and it is difficult for university leaders to apply internal accounting control to specific work practices. However, internal accounting control is very 
important for the development of colleges and universities. It needs to run through every key link in the development of colleges and universities. At the same time, all faculty and staff in each key link must comply with the implementation of internal accounting control. The leaders of colleges and universities are currently not paying enough attention to internal accounting control, and the professional literacy level of internal accounting control needs to be further improved and improved.

\subsection{Weak supervision}

At present, colleges and universities in China are generally prepared for public institutions. They mainly rely on the supervision of the education authorities in terms of finance and auditing, and many of them still enjoy certain financial autonomy. Different supervisory and management departments in the political and political departments cannot supervise and manage the supervision and management of colleges and universities. The supervision and management between different departments still have great differences in standards and systems. The external inspection and supervision departments of colleges and universities are struggling to cope with daily work. In addition, there are certain professional slogans in the budget and audit of colleges and universities, which also brings certain difficulties to external supervision and management.

\subsection{The powers and responsibilities are not clear enough}

In view of the difference between colleges and universities, in the current organizational structure of colleges and universities, the posts are set to be independent, the professional span is large, the powers and responsibilities of the functional departments are limited and not clear enough, and the leadership positions of the administrative department are mostly experts and professors. The lack of supervision and control mechanisms between them is difficult to effectively implement transparent, open, and supervised management of colleges and universities. The responsibilities of the functional department managers involved in internal accounting control are not well understood, and it is necessary to further clarify the authority and responsibilities, and promote the implementation of internal accounting control in universities.

\subsection{The professional level of the internal accounting staff of the university is not high}

Through the investigation and analysis of the background of the faculty and staff of the university engaged in internal accounting control for 10 years, it is found that the faculty and staff who are engaged in internal accounting control positions in the investigated universities have fewer faculty members in accounting or economic background. .

\subsection{Insufficient construction of campus culture}

The construction of campus culture in colleges and universities roots in the education and life of students, and the cultural construction of colleges and universities is the soul of the development of a university. It can be said that many colleges and universities now attach great importance to the education and training of students, such as a series of campus cultural activities.

\section{The Internal Accounting Control System Framework and Operation Design of Colleges and Universities}

The internal accounting control of colleges and universities is an important method and link of the internal control management of colleges and universities. Of course, the internal accounting control of colleges and universities should be combined with the characteristics of higher education institutions, that is, it should be in line with the teaching and research of colleges and universities and related administrative management. The design of the internal accounting control system framework of colleges and universities should abide by or achieve the following objectives: First, strictly abide by national laws and regulations, internal accounting control should be within the legal framework of the law; second, basically meet the objectives of risk control, especially universities Decision-making risks related to major issues: The third is to ensure the safety of financial assets of colleges and 
universities, and to prevent the loss and waste of assets; the fourth is to standardize the authenticity of financial information of colleges and universities, and stand the test: five is to optimize the funds and other related resources of colleges and universities. Configuration to improve the efficiency of resource utilization.

\subsection{Building a governance structure with organizational functions integration}

Under the conditions of market economy, colleges and universities, as the institutions of public education, have the same attributes. In the external governance structure of colleges and universities, the relationship between higher education institutions and the competent government departments should be repositioned, and the teaching, research and administrative management of colleges and universities should be clarified. Subjective status. Internally, the interaction between universities and different stakeholders should be brought into full play.

\subsection{Improve internal accounting control with institutional system}

The internal accounting control of the school must implement the methods and principles of internal accounting control, risk identification, risk assessment and other relevant management elements in the form of institutional documents. The relevant institutional documents of internal accounting control are the action plans and principles for internal accounting control of managers at all levels of the university, which can make internal accounting control well documented.

\subsection{Promote information communication improvement by efficiency sharing}

The internal accounting control of colleges and universities should be a transparent information system. The establishment of the information system should be based on the principle of efficiency sharing, and promote the information sharing among the various departments of the university. At the same time, the new system should meet the requirements of all stakeholders of the school.

\subsection{Improve the rationality of internal accounting control with budget control system}

At present, the budget management of colleges and universities needs to go through two budgets: the first is the departmental budget, which is the comprehensive budget of the school arranged by the financial department. The budget needs to be reviewed and approved by the people's congress. The budget includes the school's financial income and expenditure., the income and expenditure of affiliated units, special expenditures for scientific research in universities and other related incomes; the second budget meeting is the comprehensive budget of the university's meat department. The budget needs to be reported to the college committee for review, and the basic content of the budget is used for colleges and universities. Internal decision reference.

\section{References}

[1] Mo Shaoqun. The construction of "211 Project" and the development of the higher education institutions. China Higher Education Research, 2012(2): 12-14

[2] Lei Chaozi, Wang Weicai, Gao Junshan. Some reflections on the development of higher education institutions. Research and Development Management, 2013(3): 13-17

[3] Tian Gaoliang, Qi Baolei, Li Liuyi. Research on the influencing factors of internal control defect disclosure based on financial report [J]. Nankai Management Review, 2010 (4): 134-141

[4] Wang Haibing, Wu Zhongxin, Li Wenjun. The human interpretation of the internal control of the enterprise and the reconstruction of the framework. Accounting Research, 2011 (7): 59-65.

[5] Deng Yufen. The theoretical framework of internal accounting control in China's universities re-examination of control objectives [J]. Accountant, 2012(1): 18-21.

[6] Li Jing. Internal Accounting Control in China's University of Practice Analysis of Finance and Finance, 2012 (5): 33-34 